\title{
ASIAN BIBLICAL HERMENEUTICS AND POSKOLONIALISM; CONTESTING THE INTERPRETATIONS
}

\section{Johana Silvana Talupun}

Pengarang : R.S. Sugirtharajah

Penerbit : Orbish book, Maryknoll, New York, 1998.

Jmlh Halaman : xii + 148 halaman

\section{Pendahuluan}

Buku Asian Biblical Hermeneutics and Poskolonialism; Contesting the Interpretations ditulis oleh R.S.Sugirtharajah, seorang Profesor di bidang Biblical Hermeneutic. Ia lahir di Sri Lanka dan memiliki pendidikan pascasarjana di India dan Inggris. Sebagai seorang pakar di bidang Biblical Hermeneutic tentu banyak karya telah dihasilkannya yang berhubungan dengan studi Alkitab. Dua karya yang dirintisnya dan sangat di kenal dunia adalah teori kritis tentang studi Alkitab yaitu postcolonial criticism dan perhatiannya pada marginal interpretative voice dengan bukunya yang sangat terkenal yaitu Voices from the Margin.

Buku Asian Biblical Hermeneutics and Poskolonialism; Contesting the Interpretations yang merupakan kumpulan esai dari hasil penelitiannya di India. Tesis yang didikembangkannya adalah sebuah pendekatan hermeneutik Alkitab yang dirasa lebih cocok untuk dikembangkan di Asia. Pendekatan hermeneutik ini dipakainya untuk menentang pendekatan hermeneutik lain yang sudah dikembangkan sebelumnya. Buku ini dibagi atas dua bagian. Bagian pertama terdiri dari empat bab dan bagian kedua, tiga bab. Hasil penelitian itu menunjukkan bahwa kolonialisme telah memainkan peran yang penting pada interpertasi terhadap tradisi keagamaan baik Hindu maupun Kristen di India selama dan setelah Inggris berkuasa. 


\section{$\underline{\text { Isi buku }}$}

\section{A. Apa itu poskolonial dan hermeneutik poskolonial}

Dalam buku yang merupakan kumpulan essai ini, saya tidak menemukan rumusan Sugirtharajah tentang pengertian dasar poskolonial. Memang disadari sungguh bahwa studi tentang poskolonial bersifat interdisipliner, dengan demikian pengertian yang pasti tentang poskolonial agak sulit untuk dijelaskan. Terminologi dari istilah postcolonial itu sendiri tidak dijelaskan Sugirtharajah secara panjang lebar dalam buku ini, namun dapat dijumpai dalam bukunya yang lain yakni Postcolonial Reconfiguration: An Alternative way of Reading the Bible and doing Theology. Dalam buku ini, secara singkat ia mengatakan bahwa poskolonial bukanlah suatu tahapan historis atau periodisasi historis. Konsep ini senada dengan apa yang dirumuskan oleh Catherine Keller, seorang professor teologi di Universitas Drew, yang mengatakan bahwa istilah 'post' bukan sematamata berkaitan dengan periode atau masa sesudah kolonial, tetapi lebih menunjuk pada pengertian 'melampaui kolonial', ketika dia mengatakan bahwa 'post' in this discourse never mean simply 'after' but also 'beyond' as an ethical intention and direction (Catherine Keller, 2004, 6). Bagi Keller, terminus "post" dalam poskolonial menunjuk pada, (1) "The 'period of time following the formal separation or 'independence' of a 'colony' or group of colonies from a governing 'empire'", dan (2) "A critical idea, and so indicates the intention to go beyond the colonial in all its forms. Berdasarkan ilustrasi situasi kolonial tersebut Catherine Keller mendefinisikan, "postcolonialism is a discourse of resistance to any subsequent related projects of dominance" (Keller, 7). Istilah post yang menyertai kata colonial bukan semata-mata menunjuk pada periodisasi waktu atau masa sesudah kolonial tetapi melampaui itu. Karena setelah masa kolonial yang secara resmi dianggap berakhir sekitar tahun 1960-an, ternyata segala yang terkait dengan kolonialisme masih tersisa.

Sugirtharajah mengembangkan pendekatan hermeneutik poskolonial berangkat dari pikiran Edward Said yang terkenal dengan bukunya Orientalism dan sejumlah bukunya yang lain yang masih berkaitan dengan perspektif Barat dalam memandang Timur. Perlu ada "rekonstruksi tafsir" dalam memahami teks. Upaya ini akan berimplikasi pada penghapusan monopoli tafsir yang dilakukan 
oleh otoritas tertentu yang berbicara atas nama Tuhan, agama, dan juga kekuasaan. Tafsir yang berlaku dalam wacana poskolonial adalah tafsir yang demokratis, menegasikan kecenderungan potensi hegemonisasi, dan pemaknaan yang tidak menghendaki absolusitas terhadap pemaknaan yang diwacanakan "yang lain" (the others). Proses rekonstruksi dimaksudkan sebagai jalan pembebasan menuju pemahaman transnasional yang lebih persuasif atas sejarah suatu kaum melalui peninjauan ulang atas heterogenitas dan hibriditas. Dengan meminjam kerangka pikir Said ini, Sugirtharajah melihat bahwa pembacaan terhadap wacana agama lebih pada "pembebasan" dan melihatnya menurut keragaman budaya masyarakat yang ada. Intinya, diperlukan rekonstruksi tafsir dalam memahami teks.

Orientalisme Edward Said membawa Sugirtharajah membangun pendekatan hermeneutik poskolonial terhadap Alkitab sebagai model untuk melihat praktek-praktek penafsiran Alkitab di Asia. Karena, setelah zaman kolonial ternyata dominasi, kontrol dan penguasaan secara hegemonik masih memengaruhi banyak bidang kehidupan diantaranya teologi dan identitas kultural. Pendekatan ini ditawarkan dalam rangka memberi ruang bagi suatu proses emansipasi kultural yang selama ini didominasi oleh pemikiran kolonial. Studi poskolonial menjadi upaya untuk merumuskan identitas kultural dari kelompok masyarakat yang selama ini didiamkan.

Sugirtharaja mengungkapkan kekuatirannya jika terjadi serangan balik dari dunia Timur yang merasa identitas kultural mereka dibungkamkan bahkan cenderung dianggap tidak benar. Jika sudah terbuka ruang bagi mereka yang di dunia Timur untuk berekspresi, apakah justru tidak akan terjadi serangan balik dengan mengklaim lagi bahwa kebenaran yang berakar dari kelokan kulturan mereka yang paling benar dan akan menganggap tidak benar yang lainnya? Namun dalam bukunya yang lain, Sugirtharajah $(2001,247)$ kekuatirannya dijawab dengan menegaskan bahwa dengan pendekatan ini tidak berkonotasi meromantiskan serta mengagungkan lokalitas dengan kulturnya dan menelanjangi serta mencari keburukan dari kolonial sebagai bentuk anti-kolonial. Sebaliknya poskolonial menjadi media untuk secara kritis melihat kultur kolonial maupun lokal. Jadi, pendekatan ini memberi kritikan pada dominasi kolonial tetapi juga 
lokal dapat saja terjadi. Sekalipun menawarkan pendekatan poskolonial dan memberi ruang bagi budaya lokal namun tidak lalu mengambil posisi baru dan menempatkan budaya lokal sebagai yang paling benar sehingga dengan kebenaran itu berjuang dan menghantam lagi budaya kolonial.

Saya setuju dengan Sugirtharaja sebab suatu budaya yang berkembang pada masyarakat lokal di manapun, sudah mengalami hybrid pada satu konteks tertentu sehingga budaya yang paling 'asli' hampir tidak bisa dijumpai lagi. Maka sikap kritis menjadi tawaran untuk memandang budaya kolonial maupun budaya lokal. Dengan kata lain pendekatan poskolonial memberi kesempatan bagi penafsir lokal untuk melakukan interpertasi bahkan menerjemahkan Alkitab dengan mengindahkan pengalaman budaya masyarakat lokal namun tetap harus menunjukkan kekritisannya sehingga bisa pula melakukan kritik pada budaya lokal ketika itu dipandang perlu.

\section{B. Alasan Dasar Tawaran Hermeneutik Poskolonial}

Dalam buku ini, ada 4 alasan yang mendorong Sugirtharajah menawarkan Hermeneutik Poskolonial dalam membaca dan menginterpertasi Alkitab yaitu :

1. Tiga model interpertasi Alkitab yang dikembangkan di India

Pemaparannya dalam buku ini dimulai dengan mengedepankan hasil survey yang dilakukannya di Asia (khususnya India) kemudian mengidentifikasi tiga model/bentuk interpretasi Alkitab yang menurutnya berasal dari era kolonial. Ketiga model/bentuk ini adalah "Orientalis," “Anglisist," dan "Nativist'. Ia mencoba menjelaskan tentang ketiga model interpertasi Alkitab tersebut dengan menghadapkan kekuatan dan kelemahan dari masing-masing yang dipraktekkan di India selama dan setelah zaman kolonial.

\subsection{Model orientalist (hlm.4-8).}

Interpretasi Alkitab modern di India dimulai dengan apa yang sekarang dikenal sebagai fase "Orientalis" (the "Orientalist" phase). Orientalisme merupakan kebijakan kultural yang dianjurkan oleh para kolonialis sebagai cara mempromosikan dan menghidupkan kembali warisan bahasa, filosofi maupun tradisi religius lokalnya. Ketertarikan mereka merupakan instrument dalam 
penggalian budaya India masa lalu sehingga memberikan perasaan bangga pada sejarah lokal mereka. Pendekatan. model orientalis ini berupaya mempelajari teksteks kuno masyarakat lokal dengan maksud untuk melihat kesamaan dengan Injil. Teks-teks kuno dimaknai sebagai persiapan untuk Injil dan maknanya disempurnakan oleh Injil. Sugirtharajah memakai contoh karya Krishna Hona Banerjea (1813-85) yang memerlihatkan perpindahan orang Bengali yang kemudian menjadi penganut iman Kristen (The Ariant Witness). Buku The Ariant Witness memperlihatkan bahwa (a).Veda mempunyai kedekatan dengan semangat Kristianitas daripada Kitab-kitab Ibrani; (b).bentuk murni dari pristine Hinduisme ditemukan yang dalam Veda itu adalah identik dengan Kitab Suci Kristiani; (c) untuk merepososi Kristianitas India kontemporer sebagai warisan spiritual (spiritual heirs) dari Aryan Hindus; dan (d) untuk memproyekkan Hinduisme Vedic sebagai sebuah persiapan untuk keyakinana yang bersifat Alkitabiah (hlm. 4-5).

Interpretasi Alkitab yang bersifat Orientalistis berfungsi pada 2 level yaitu pertama, untuk memampukan para penganut India lokal untuk memiliki sebuah identitas publik patriotik guna menentang penilaian atau pernyataan negatif tentang India yang dilakukan oleh para missionaries dan administrator kolonial. Dengan mempelajari teks-teks lokal, maka ada penghargaan terhadap identitas lokal. Kedua, memampukan orang-orang Kristen India kemudian untuk mengungkapkan kembali Kekristenan yang khas India (hlm.7). Usaha para Orientalists untuk mendokumentasikan dan menemukan kembali India berakibat pada konstruksi dari sebuah tradisi khusus yang telah menyamakan India dengan Hindu-Aryan, yang mengistimewakan teks-teks Sanskrit dan mengabaikan tradisitradisi rakyat asli India. Para Orientalist juga mengabadikan sebuah image tentang seorang India spiritual yang berlawanan dengan seorang Barat yang materialis pada masa perubahan ekonomis dan sosial yang terjadi begitu cepat. Namun hal yang tidak disentuh oleh Hermeneutik Orientalis dan ini dianggap sebagai kelemahan model ini adalah apa yang menjadi persoalan riil yang justru dialami oleh masyarakat India seperti persoalan ketidakadilan gender, bencana kultural yang terjadi pada orang-orang dari suku-suku asli, juga kerusakan hutan dan lingkungan (hlm.8). 
1.2. Model Anglicist (hlm.8-12)

Anglisisme muncul sebagai sebuah upaya ideologis untuk menghadang Orientalisme kolonial di India. Hal itu merupakan sebuah usaha strategis untuk menggantikan teks-teks pribumi (indigenous texts) serta suatu proses pembelajaran yang menggunakan ilmu Eropa dan mode-mode pemikiran orangorang Barat dan mengintegrasikannya ke dalam kultur dari sang colonizer (hlm.8). Para pionernya di kalangan Anglisist adalah para administrator T.B. Macaulay dan Charles Trevelyan, dan Alexander Duff, misionaris Gereja Skotlandia pertama ke India. Kalau para Orientalist sungguh-sungguh mengagumi warisanwarisan agama, kultural dan tekstual dari masa lalu India, maka kaum Anglisist tidak begitu. Kaum Anglisist justru menganggap bahwa pendekatan-pendekatan lokal adalah tidak ilmiah dan dianggap salah. Literature Inggris dan sastra Inggris dan ilmu-ilmu yang berciri Eropa dianggap sebagai suatu kebenaran lalu mendiskreditkan teks-teks Hindu dari Orientalis sebagai suatu kesalahan.

Model Anglicist menggantikan pendekatan naratif yang sering dipakai oleh orang India dalam menginterpertasi Alkitab. Orang India melihat teks sebagai keseluruhan narasi yang tanpa pengarang (authorless narrative wholes) dan tidak mempedulikan segi historisitasnya - asal muasalnya atau situasisituasinya di mana teks-teks itu disusun, atau pembuatan tekstualitas atau narativitasnya - namun mencari sebuah kisah manusia. Model Anglicist sangat kuat dengan Eropa sentries dan menduduki posisi superior terhadap agama-agama Asia maupun agama lokal yang dianggap tidak historis dan irasional karena memberi pandangan negatif bagi pendekatan lokal di Asia.

\subsection{Model Nativist (hlm.12-18)}

Nativisme merupakan suatu upaya untuk mengangakat kembali tradisi-tradisi pribumi atau tradisi rakyat yang selama ini berada dalam bayang-bayang tradisi ningrat (hlm.12). Dalam interpertasi nativistik, cerita-cerita rakyat dan legendalegendanya dipakai sebagai sarana untuk menyampaikan pesan-pesan moral, ajaran-ajaran religius dan ajaran-ajaran doktrinal. Model Nativistik ini memang memberi ruang bagi pengembangan gagasan-gagasan lokal sehingga komunitas 
Kristen dapat menafsir dan memaknai Alkitab dalam bahasa mereka sendiri. Namun interpretasi nativistis berdampak negatif pada partikularisme dan isolasionismenya sehingga menjadi tidak relevan dengan mayoritas di luar dari wilayahnya dan cenderung eksklusif.

Saya setuju dengan pendapatnya ini karena interpretasi nativistis melanggengkan gagasan tentang budaya lokal sebagai yang bersifat statis, tidak berubah, dan cenderung mengidealisasikannya. Dalam dunia yang mengglobal ini, memang agak sulit untuk berbicara tentang suatu budaya yang murni, karena tidak ada budaya tanpa pengaruh globalisasi. Jika demikian maka budaya lokal itu sendiri justru akan menjadi kaku.

Berangkat dari analisa ketiga model Alkitab yang berkembang di India, maka Sugirtharajah menawarkan satu model/bentuk yang baru yaitu penafsiran poskolonial. Model penafsiran poskolonial tidak berupaya untuk menemukan satu makna tunggal terhadap teks Alkitab yang ditafsir, namun akan memeriksa unsurunsur kolonialisme yang ada pada teks. Poskolonialis adalah perolehan identitas baru. Artinya bahwa dulu identitas yang alami dari suatu masyarakat lokal dengan ciri budayanya yang dianggap sebagai suatu sinkretisme dan dianggap negatif pada zaman kolonia, poskolonial justru melahirkan konsep dan nilai-nilai baru. Bukan sekedar perjumpaan dan interaksi dengan budaya lokal seperti yang menjadi ciri dari Orientalis, Anglisist dan nativist.

Pendekatan postkolonialitas akan mendorong lahirnya upaya interpretasi Alkitab secara luas, baik di India maupun di Asia. Dengan interpertasi poskolonial maka narasi-narasi Alkitab akan dipertanyakan dengan pertanyaan-pertanyaan ideologis dan teoretis yang sama yang ditempatkan pada teks-teks lain. Tidak seperti mode-mode Orientalis, Anglisis, dan nativist, poskolonial tidak akan masuk dalam mengembalikan makna tunggalnya dari teks itu, namun akan menggali teks-teks itu terhadap kode-kode kolonialnya yang implisit atau eksplisit. Sugirtharajah juga mengutip pendapat Shohat dalam buku, Notes on the Post-colonial; social text, Notes on the Post-colonial; social text, yang mengatakan bahwa bagaimanapun, tidak seperti pendekatan-pendekatan Orientalis, Anglisist, nativist, pembacaan poskolonial akan menggali masa lalu itu, "bukan sebagai fase pemujaan yang statis untuk direproduksi secara literer, 
namun sebagai kumpulan-kumpulan memori dan pengalaman yang diceritakan secara terpisah-pisah untuk memobilisasi komunitas-komunitas kontemporer"

2. Alkitab berisi kandungan Imperial dan sarat dengan ideologi (hlm.18-24)

Jika membaca judul pada bagian ini, maka orang akan menduga bahwa yang ditekankan Sugirtharajah semata-mata adalah kebebasan interpertasi terhadap teks kitab suci yang diberikan kepada interpreter di dunia Timur guna menghindari hasil interpertasi yang berciri imperial. Namun lebih dari pada itu, penekanan Sugirtharajah adalah bahwa Alkitab sendiri sesungguhnya berisi kandungan imperial. Bagi Sughirtarajah, Alkitab adalah sebuah produk sastra (literary product) dari dunia purba, yang dihasilkan untuk mewujudkan maupun melegitimasikan keinginan kolonial, asumsi-asumsi kolonial dan kekuasaannya. Kebanyakan dari tulisan-tulisan di dalam Alkitab ditempatkan dalam sebuah konteks imperial dan dibuat untuk melayani impuls-impuls militeristis, ekspansionis dari Israel dan untuk menanggapi mereka yang dari Mesir, Syria, Persia dan Roma. Ia mencontohkan kisah Ester dalam Perjanjian Lama serta figur Yesus dan Paulus dalam Perjajian Baru. Kisah Ester merupakan sebuah kisah kolonial yang di dalamnya Ester menjadi orang yang terkolonisasi. figur yang tidak menantang asumsi-asumsi dari kekuasaan Persia yang dominan, malah berusaha mendapatkan sebuah mode perjuangan untuk hidup dan tidak menantang sistim yang berlaku di situ. Kitab Ester menawarkan strategi inkorporasi dan asimilasi. Dengan menggunakan strategi-strategi ini, Ester akhirnya diterima ke dalam keluarga kerajaan itu dan Mordecai menerima sebuah kesepakatan dalam pemerintahan/administrasi kolonial itu.

Yesus dan Paulus dalam Perjanjian Baru adalah dua tokoh yang mengalami dampak dan efek dari kolonialisme. Pelayanan Yesus ditempatkan dalam konteks politis imperialisme Romawi, namun hampir tidak ada bukti atau fakta tentang kritikan Yesus yang secara langsung mengkritisi Penguasa Romawi atau kekuasaan raja Herodes. Kritikannya justru langsung ditujukan kepada orangorang lokal yang bersekongkol dengan penguasa Romawi dan menggunakan sistem Kenisah secara efektif untuk meningkatkan peran mereka. Demikian juga Paulus, seorang imigran yang banyak melahirkan tulisan, terkesan dalam tulisan- 
tulisannya bahwa ia sudah secara penuh dipengaruhi oleh sistem imperial itu. Dalam Roma 13, ia menggambarkan nilai-nilai kolonial dengan menegaskan bahwa Allah dan sejarah berada pada pihak Kekuasaan Romawi. Menurut Paulus, hal yang penting bagi orang-orang Kristen adalah hidup secara damai dengan penguasa kolonial dan bekerja dalam bingkai kekuasaan itu, daripada memberontak terhadapnya. Kemahakuasaan Romawi tidak dipertanyakan dalam surat-suratnya, kecuali dalam term-term teleologis. Kadang kala ia mengecam kejahatan-kejahatan dari sang penguasa, namun tidak memberikan strategi politik atau solusi praktis untuk pengurangan kekerasan atau kejahatan itu.

\section{Perdebatan antara para penafsir yang berbeda}

Setelah bab satu, bab selanjutnya lebih banyak menunjukkan contohcontoh dari bentuk penafsiran yang dilakukan di india. Ternyata ada berbagai bentuk hasil tafsir dan perdebatan yang terjadi di antara para penafsir, misalnya antara missionaries Kristen dengan reformis Hindu. Perdebatan juga terjadi antara penginjil imperial dengan praktisi hermeneutuk liberal, perbedaan sikap para komentator hermeneutik yang liberal dengan para misionaris, yang terletak pada tujuan dan metode. Tidak hanya dalam soal penafisran Alkitab tetapi pengaruh kolonialisme itu juga nampak dalam soal penerjemahan Alkitab yang sangat bias ras dan kelas. Ada dominasi penerjemahan dan interpertasi antara kelas yan memposisikan dirinya sebagai yang superior terhadap ras inferior dengan argumen bahwa terjemahan yang dilakukan oleh ras superior akan membuat orang-orang lokal menjadi orang-orang yang beradab baik secara moral maupun intelektual. Bahkan senada dengan Kwok Pui Lan, teolog permpuan yang menekankan pendekatan feminis terhadap pembacaan Alkitab, membedakan antara pembaca akademis dan non akademis.

Terhadap realitas itu maka Sugirtharajah menawarkan strategi penerjemahan poskolonial yaitu pertama, melihat keterhubungan intertekstualitas antara teks Alkitab dengan kitab suci Asia. Teks-teks Asia dipakai untuk menerangi teks Alkitab. Kedua, teks-teks religius Asia dihargai sebagai teks yang memiliki keunikan tertentu dalam tradisi suci Asia sehingga tidak ada upaya untuk membersihkannya dengan terang Alkitab. George Soares Prabhu pernah 
membandingkan antara teks Alkitab dengan teks Budhis walaupun keduanya memiliki sastra dan konteks yang berbeda. Tentu saja ada kesenjangan di antara kedua teks itu karena konteksnya yang berbeda. Hermeneutika intertekstual yang dipakai guna menjembatani kesenjangan yang tercipta dan ada pencerahan. Sikap George ini juga mendorong lahirnya teologi pembebasan di Asia dengan tidak hanya berdasar pada Alkitab saja tetapi juga memperhatikan berbagai tradisi cerita dan teks suci yang ada di Asia. Keduanya bisa saling melengkapi dan menerangi dalam suatu dialog.

Dalam konteks sekarang, berbagai perdebatan seperti yang disebutkan di atas bukan hanya di India. Perdebatan antara kaum awan dan teolog, antara kaum awam yang berbeda latarbelakangb pendidikan, status sosial, budaya dan lainnya. Perdebatan adalah hal yang lumrah sebagai sebuah upaya untuk saling memperkaya. Namun jika kebebasan tanpa kekritisan maka yang terjadi adalah hasil bacaan dipakai untuk menekan orang lain, mengedepankan dan memaksakan ideologi tertentu kepada orang lain. Jika itu yang terjadi, maka lingkaran kolonialisme akan terus berlanjut. Yang dimaksudkan kebebasan membaca dan menginterpertasi adalah pembaca atau interpreter harus mampu menunjukkan kekritisannya.

\section{Konsep Kristologi yang berciri Eropasentris}

Selain penafsiran dan penerjemahan Alkitab yang berciri Barat sebagaimana dikritisi Sugirtharajah, ia juga mengkrtisi konsep Kristologi yang dinilainya juga bercorak Eropasentris. Ini nampak dalam berbagai penelitian historis tentang Yesus sampai pada upaya untuk menunjukkan wajah Yesus yang juga cenderung bercorak Eropa. Memang, sampai sekarang, gambar-gambar Yesus yang sering menghiasi rumah orang Kristen adalah gambar Yesus yang berciri Eropa sentris. Walaupun sebetulnya dalam upaya kontekstualisasi sudah ada gambar wajah Yesus yang bercorak Jawa, Irian dan yang lainnya. Sisa peninggalan Eropa/Barat ini juga yang dikritisi oleh Sugirtharajah

Penelitian yang bercorak Eropa sentries (Barat) ini mendominasi Kekristenan sehingga mendiamkan dan menghapus kemungkinan pengaruh pemikiran agama Timur dalam ajaran dan gaya hidup Yesus. Hal ini dipengaruhi 
pandangan bahwa segala sesuatu yang bernilai teologis hanya dapat berasal dari tradisi Yunani-Yahudi. Eropa sentries memiliki premis ganda di mana Yunani menjadi akar dari intelektual dan filosofis, sedangkan Yahudi menjadi akar religius yang asli. Bahkan para penulis bibliografi Yesuspun mengabaikan kontribusi pemikiran Timur karena dianggap sarat dengan tahyul, sia-sia dan tidak ada kontribusi yang signifikan terhadap munculnya kekristenan dan perkembangan teologi. Mestinya ketika bicara tentang Yesustidak bias melepaskan tiga konteks; Yahudi, Yunani dan agama Timur.

Suatu agama tidak berkembang dengan sendirinya. Mesti diakui bahwa perkembangan agama itu selalu berinteraksi dengan yang lainnya. Memang ada kekhasan tersendiri dari agama tersebut namun tetap ada kombinasi unsur-unsur tertentu dari agama tersebut dengan agama yang lainnya. John Hull sebagaimana dikutip Sugirtharajah mengatakan bahwa setiap tradisi agama yang lahir di dunia tidak lahir dalam kesendirian namun saat suatu tradisi agama lahir sudah ada agama-agama yang lain. Dengan demikian, dalam perjumpaan itu akan ada dialog yang terus berkembang dengan melihat unsur-unsur yang universal dari pesanpesan Yesus. Dialog itu akan membantu melihat persamaan dan perbedaan yang ada pada masing-masing agama dan melakukan kritik budaya dan kritik ideology yang ada pada kekristenan maupun tradisi agama lain.

Marcus Borg menawarkan upaya untuk melihat koneksitas antara hasil penelitian para penulis sejarah Yesus dengan pengalaman sehari-hari dari orang percaya. Karena dalam konteks Asia, yang penting adalah bukan apa yang tampak dalam historikal Yesus, tetapi apa yang berarti secara signifikan bagi masyarakat. Saya setuju bahwa historokal Yesus tidak berarti jika tidak mengalami koneksitas dengan pengalaman keseharian.

\section{Penutup}

Sugirtharajah telah meletakan suatu dasar yang baru dalam dunia penafsiran Alkitab bahwa kini telah terbuka ruang bagi masyarakat di Asia untuk bebas melakukan pembacaan terhadap Alkitab. Suatu ruang yang dengannya masyarakat tidak harus terikat pada pembacaan dan penafsiran Alkitab dari dunia Barat yang tentunya sangat dipengaruhi oleh konteks yang terjadi di dunia sana. Setiap 
pembaca diberi kesempatan untuk membaca dan menafsir teks Alkitab dengan mempertimbangkan latar belakang budayanya.

Pada bagian tertentu, Sugirtharajah menunjukkan bahwa teks Alkitab itu sendiri perlu dikritisi dan bukan sekedar hasil pembacaan atau hasil tafsirnya. Memang ini menarik dan baik sekali jika teks yang dikritisi itu dipandang dari sudut tertentu walaupun hal itu sendiri bisa juga melahirkan suatu persoalan. Persoalan baru yang bisa saja muncul adalah bisakah teks Alkitab dikritisi? Lalu di mana kewibawaan Alkitab sebagai kitab yang memiliki otoritas tersendiri bagi pemeluk agama yang memilikinya? Bagi Sugirtharajah, teks Alkitab adalah suatu produk sastra (literary product) dalam dunia purba. Sebagai suatu produk sastra yang lahir dari suatu konteks tertentu maka tentu saja tidak akan luput dari kepentingan tertentu pula yang menjadi target dari produk sastra tersebut. Karena itu Sugirtharajah dengan tegas menunjukkan posisi barunya sebagai orang yang berdiri pada posisi yang berbeda dari sebelumnya. Namun catatan kritis saya bagi Sugirtharajah maupun penganut Sugirtharajah adalah bahwa meskipun posisi baru poskolonial membuka ruang untuk membaca dan menafsir teks dengan tidak selalu mengagungkan interpertasi Barat sebagai yang paling benar dan harus diikuti, namun sejalan dengan itu pula maka pembaca di dunia Timur tidak sertamerta menganggap dan memaksakan hasil bacaannya sebagaiyang paling benar dan menyalahkan hasil pembacaan yang lama. Mesti ada upaya untuk melakukan dialog dengan pembacaan dari dunia dan kultur yang berbeda. Saya kira apa yang dirintis oleh Hans de Wit dengan tawaran intercultural hermeneutic-nya adalah sesuatu yang menarik. Penafsiran intercultural cenderung bersifat deskriptif guna menggambarkan apa yang terjadi ketika interpertasi dilakukan dalam kerangka konsep dialog intercultural. Proyek ini bertujuan untuk menghasilkan suatu dialog yang lahir dari situasi lokal. Dalam dialog itu ada dua kelompok yang diberi kesempatan masing-masing untuk membaca teks Alkitab yang sama secara terpisah dan pada waktu yang lain akan bertemu untuk melakukan dialog. Dalam dialog itu tentu saja akan lahir kritikan dari masing-masing kelompok. 